CRÍTICA, Revista Hispanoamericana de Filosofia

Vol. XXII, No. 66 (diciembre 1990): 87-114

\title{
ON THE POSSIBILITY OF LAWFUL EXPLANATION IN ARCHAEOLOGY*
}

MERRILEE H. SALMON

Department of History and Philosophy of Science University of Pittsburgh

Serious concern with lawful explanation in archaeology is a relatively recent phenomenon. It coincides with a philosophical surge of interest in explanation during the past three or four decades. "New" archaeologists of the 1960's and 1970's expressed respect for the detailed taxonomies and cultural sequences constructed by their predecessors, but they were more ambitious. They wanted scientific explanations of such matters as why prehistoric peoples shifted from hunting and gathering to agriculture, why population centers developed and were abandoned just when they were, and why whole civilizations rose and fell. Ethnocentrically-biased analogies or plausibility considerations rather than hard evidence supported earlier archaeologists' accounts of these phenomena. New archaeologists insisted on the possibility of lawful explanation.

In considering lawful explanations in archaeology, I will be concerned primarily with explanation of why particular features occur at an archaeological site or why archaeological discoveries have the features they do. It is at this level that archaeological theory is literally brought down to earth and tested in

- The author is indebted to the other participants in the symposium on Explanation and Laws, sponsored by the Instituto de Investigaciones Filosóficas (UNAM), for helpful discussion and to Jeremy Sabloff, who read and commented on an earlier version of this paper. 
practice. Obviously, such small-scale phenomena must be accounted for if archaeology is to go on to provide large-scale explanations of social, behavioral, and cultural change.

Although the new archaeologists proclaim and are noted for their commitment to the aims and practices of science, this commitment does not adequately characterize the novelty of their position. As Alison Wylie (1990) points out, archaeologists at the turn of the century had proclaimed the need to seek scientific proof for their claims and to follow standard scientific practices in gathering and recording archaeological data. New archaeologists in the latter half of the twentieth century, however, focussed on problems of explanation, turning to philosophy of science to acquire understanding of scientific explanation and confirmation. (Binford, 1972: 7-8; Watson, LeBlanc, and Redman, 1971, 1984.)

New archaeologists believed that modern technologies would continue to improve their data base, which was already adequate for many of their explanatory questions. Extracting knowledge from those data was the problem. The key to acquiring knowledge, they believed, was the proper scientific method, as set forth in the writings of contemporary philosophers of science, especially Hempel and Oppenheim's classic paper (1948) and Hempel's introductory text, Philosophy of Natural Science (1966).

New archaeologists urged their colleagues to adopt as ideal standards of scientific reasoning in archaeology the deductivenomological model of explanation and the hypothetico-deductive model of confirmation. Not surprisingly, however, difficulties arose when they tried to construct covering-law explanations. For a time, discussion concentrated on establishing suitable explanatory laws. Archaeologists argued about how to distinguish laws from mere generalizations, about whether there were any genuine archaeological laws, and whether laws really are essential to scientific explanations. In response to these problems, some archaeologists professed an unwavering faith 
that laws would be found, and offered examples of admittedly low-level archaeological laws, such as Schiffer's "Loss probability [the probability that an object will be lost] varies inversely with an object's mass" (1976: 32). Others derided this approach, characterizing the so-called laws as trivial-“Mickey Mouse laws", Kent Flannery called them. Still other archaeologists looked for alternatives to Hempel's models of explanation that did not require laws. For example, Tuggle and his coauthors (1972) presented a "systems approach" to explanation, based on E. Meehan's Explanation in Social Science-A Systems Paradigm (1968). In this work, Meehan, a political scientist, argued that because of the problematic status of laws in the social sciences, adopting the standard covering-law models in those disciplines was inappropriate. In his proposed "systems model", regularities, but no laws, are required. Archaeologists who believed that their discipline should be more closely aligned with the humanities than the social sciences felt their own position strengthened by problems about discovering laws of archaeology (Trigger, 1978). Philosophers of science entered the fray, pointing out archaeologists' failure to comprehend Hempel's models adequately (Morgan, 1973). They also noted problems with Hempel's models as well as the lack of agreement among philosophers about how best to model scientific explanations (Salmon and Salmon, 1979).

Robert Dunnell (1989) says that archaeologists lost interest in the problem of explanation when they saw that philosophers of science disagreed about the correct model of science. Some support for Dunnell's view comes from noting that in the 80's discussions of archaeological explanation shifted away from standard philosophical questions about the nature of laws and the formal properties of explanation to their content. This change in interest is reflected in the new title Archaeological Explanations as well as different focus and content of what was to have been simply a second edition of Watson, LeBlanc and Redman's Explanation in Archaeology, a manifesto of new ar- 
chaeology. Nevertheless, I will argue that although the focus of discussion has shifted, questions concerning lawful explanation remain important and unresolved issues in archaeological theory. While some archaeologists turn away from philosophical debates, others continue to press for a philosophically satisfactory account of archaeological explanation.

In a limited sense, archaeologists' commitment to lawful explanation is indisputable. Working archaeologists, whatever their theoretical leanings, use laws that were discovered or formulated in other disciplines to interpret archaeological remains. For more than a century, they have depended on geological principles of stratification and superposition to assign relative dates to archaeological materials. Today they rely on physical laws of radioactive decay and on biological laws governing tree ring growth to assign absolute dates. Using sensitive microscopes capable of detecting minute differences in the texture of lithic materials, archaeologists invoke physical laws of abrasion to analyze patterns of wear on prehistoric implements. Thus, the microscopically detectable surface features of the edge of a worked flint tool might be explained by saying these features result from pressure-contact with animal hides. Archaeologists recognize that poor preservation or contamination of materials and their contexts can lead to mistaken interpretations and that refinement of techniques for application of the laws are possible, but the use of such laws in archaeological practice is generally regarded as uncontroversial.

Archaeologists, moreover, do not question whether physical sciences employ lawful explanation, nor do they doubt the existence of laws of nature. Generally, they are quite happy to avail themselves of any physical, chemical, or biological law that can help solve problems that interest them. So far at least, the archaeological literature is unaffected by the sorts of doubts van Fraassen raises in Laws and Symmetry (1989) about the existence of laws and their importance for science. Many archaeologists, however, are skeptical about whether it is possi- 
ble to find explanatory laws that connect particular instances or patterns of human behavior with material remains. Thus it is in the context of archaeology as a social or behavioral science that the controversial questions about lawful explanation typically arise.

One common type of question which archaeologists try to answer is why a particular kind of object or feature is found in a given archaeological context. Answers often take the form of stating the function of the object or feature. Why, for example, are the large water storage jars (ollas) found in Sonoran desert sites made of slightly porous clay? Because the porosity, which is achieved by using an organic temper that burns away in firing, permits evaporative cooling of the water. Functional ascriptions such as this are often based on arguments from analogy. Specifically, archaeologists infer that the function of an artifact (or feature) found in an archaeological site is the same as that of some ethnographically or historically known object when the forms of the two are analogous. This is true of the account of the ollas just given. Papago Indians living in the Sonoran desert were using ollas for storing drinking water at the time of European contact. They showed the newcomers how it was done, and both groups used ollas to store water until the advent of modern refrigerators. Implements, identified as cornscrapers, which Flannery and Winter found in archaeological sites in Oaxacan caves, provide another example. The form of these implements, including such detailed features as patterns of edgewear, was identical to that of implements used by contemporary Oaxacan farmers for scraping kernels from corncobs (1976).

Attributions of function provide a fundamental link between material remains and the behavior of people known only through their remains. We would hardly know how to describe archaeological findings without a functional-ascription vocabulary. "Bowl", "jar", "roof", "scraper", and "blade", for example, are all functional terms. Their archaeological use is 
grounded in implicit arguments from similar form to similar function. Although many functional ascriptions seem unproblematic, not all inferences from form to function are reliable. Objects of similar form can be destined for different functions, and similar functions can be served by objects of diverse forms. Questions obviously arise about how to assign functions to archaeologically found objects when no ethnographic or historical analogues are known. Assigning all such objects to the remainder category of "ritual function" is an archaeological joke. Moreover, since perceived similarities of form depend to a large extent on the interests of the perceiver, mistakes can easily occur.

New archaeologists have been particularly critical of their predecessors (usually labeled "culture historians") for their unsubstantiated and sometimes whimsical assignments of functions. New archaeologists in turn are criticized by postprocessual archaeologists for ascribing only utilitarian functions to objects and refusing to pay attention to symbolic and meaningful aspects of human behavior. Strong political overtones color the current debate, with new archaeologists now being cast in the role of archconservatives who enforce their view, stereotyped by modern conceptions of male-female roles and political arrangements, of humans grubbing out a living by reacting to a usually hostile physical environment. The postprocessualists who paint this picture regard themselves as innovative, open-minded investigators of material evidence for the symbolic means by which humans actively create and define their environments. Whereas Hempel's naturalistic view of a science of human behavior is taken as a model by the new archaeologists, the postprocessualists turn to interpretivist accounts, such as that of R. G. Collingwood (Hodder, 1985, 1987a; Salmon n.d.). An extreme version of postprocessualism expresses views similar to those of critical theorists associated with the Frankfurt school. It regards any attempt to model a science of human behavior on the physical sciences as a ploy of dominant 
Western political ideology which is used to manipulate humans and to justify the maintenance of an unfair and discriminatory set of social practices (Shanks and Tilley, 1987).

Problems about justifying the ascription of functions are related to the question of lawful explanation and will be taken up later. First, however, I will try to answer three questions: Has the presence of an item in the archaeological record been explained when its function is identified? If so, are such explantions dependent on laws? Finally, if a positive answer is given to our second question, what can we say about such laws?

To answer the first question, we need to look at what it means to ascribe a function to an object. In the archaeological literature "function" is rarely defined precisely, but is usually characterized as that which an item is good for or used for with respect to some specific task. ${ }^{1}$ Larry Wright, in his careful analysis of functional ascriptions (1976), insists, however, that attribution of function involves more than merely saying that the object is good for or used for some task at hand. He says that when we ascribe a function to a human artifact, we imply that the object was selected, designed, created, or modified to accomplish the desired outcome. This in turn says something about why the object came to be, or came to be where it is, or has the form it has. In this way functional ascriptions say something about the causal history of the item with the function. Insofar as functional ascriptions provide a causal etiology, they have, Wright insists, explanatory force.

In contrast to Hempel (1965) and Nagel (1977), who distinguish functional ascriptions from functional explanations, Wright argues that "the simple attribution of a function ipso facto provides that explanation (ascription-explanation) [of why

1 R. Dunnell (1978) does offer a definition: "Function is manifest as those forms that directly affect the Darwinian fitness of the populations in which they occur." This nonstandard definition has not received wide acceptance. 
the item is there], just as does the simple attribution of a goal to behavior" (1976: 80).

Wright offers the following standard formulation of such ascription-explanations:

The function of $X$ is $Z$ iff:

$Z$ is a consequence (result) of $X$ 's being there;

$X$ is there because it does (results in) $Z$ (1976: 81).

His use of the expression "is there" in this formulation is deliberately unspecific (1976: 81-82). In one context, the expression might mean "exists (at all)" (ollas are there to store water); in another, "objects have them" (ollas have slightly porous bodies to promote evaporative cooling).

The explanatory force of functional ascription depends heavily on distinguishing between the function(s) of an item and any other incidental or accidental purposes it might be good for or used for. For example, sewing shears might be used as a murder weapon, but that is not their function. Serving as murder weapons is not part of the causal story of how sewing shears came to be designed, manufactured, or found in sewing baskets. The exquisite decoration on Mayan pottery bowls has resulted in enriching the pockets of dealers who trade illegally in antiquities, but that is not the function of the decoration. In other words, the decoration is not there because it results in enriching traders, though it has that result. Only the first clause of the formulation that characterizes a function is fulfilled. In ordinary language, we often use the expression "function as" to acknowledge the distinction between the function(s) of an object and other things it might be good for. For example, "The screwdriver functions as a window opener, but that is not its function."

Whereas a sharp distinction must be drawn between an object's function (or functions) and its other "accidental" uses, the term should not be restricted to utilitarian or practical functions. Although in some contexts, it is appropriate to describe 
a feature as "nonfunctional, merely stylistic", the categories of function and style are best understood as coextensive rather than mutually exclusive. So-called stylistic features of objects frequently serve nonutilitarian expressive functions, and occasionally even utilitarian ones. Wright's account of function can accommodate symbolic and expressive functions as well as practical functions. A brief discussion of some relationships between "function" and "style" will clarify this point.

Art historians, archaeologists, literary critics, and others have offered various analyses of "style". One of the most useful analyses for archaeology, I believe, is that of Gombrich (1968) and Sackett (1982). They argue for a usage in which "style" represents the availability of alternatives or choices among various ways to accomplish some task. The task might be utilitarian (such as storing food) or symbolic (such as displaying status). The choices referred to can include craft traditions in a given culture as well as conscious individual choices. For example, consider a bowl made to store seed for next year's corn crop. The bowl's utilitarian function constrains its shape, size, and material composition to some degree. But even when operating under the functional imperative of making a seed storage bowl, an artisan is free to exercise some choices. She can, for example, paint on the exterior of the bowl or leave it unpainted. In the situation as described, a painted exterior is a stylistic feature of the bowl. Alternatives that are functionally equivalent with respect to seed storage are available to the artisan. Consider a different scenario, however, in which the artisan is a member of the rabbit clan in a culture which requires representing the totem animal on seed storage bowls. The painted design has the function of symbolically expressing or affirming cultural beliefs. The alternative of an unpainted seed storage bowl is not an available choice from the perspective of behaving in the culturally approved way. Of course, some stylistic variation is possible in the way in which the rabbit is painted, just as some degree of stylistic variation is possible with respect 
to size, shape and material of the bowl. Style and function on this view are relative and complementary notions. Separating them analytically requires detailed contextual knowledge, for unless we can discern both the function of the artifact and the range of alternatives available to its maker, we cannot judge with any accuracy whether a given feature represents stylistic choice. Moreover, the judgment that a feature is stylistic does not preclude attributing a function to that feature.

Despite conflicting intuitions about the concept of style and complexities in the accounts offered by various authors, stylistic variation has been immensely important to archaeologists because the choices style represents allows them to identify ethnic groups and to track their interactions. Wright's account of ascription-explanation accommodates expressive or symbolic functions of features that could be judged stylistic from a utilitarian perspective. Thus it accords well with postprocessual archaeologists' interest in the functional roles of stylistic variation. Stylistic features such as decorative painting on food containers, for example, not only can express cultural values but also can convey important information about the environment. A recently discovered, beautifully painted Mimbres bowl, for example, apparently depicts the important astronomical event that occurred in 1054 A.D. The account of functional ascription offered here should forestall the criticism that postprocessual archaeologists direct at new archaeologists for focusing too closely on "functional" or "passively adaptive" aspects of human behavior and not attending carefully enough to its symbolic or creative aspects.

Wright's account of functional ascription-explanations is, to my mind, the most detailed and satisfactory available, and is particularly appropriate to archaeological theory, since artifacts designed by humans serve as paradigmatic cases for his analysis. With his account of the nature of functional ascription in hand and with an understanding that "function" includes expressive as well as utilitarian functions, we are ready to turn 
to our second question: Are functional ascription-explanations dependent on laws?

One way to try to answer this question is to see whether functional-ascription explanations conform to any of Hempel's covering-law models. These are, after all, the standard examples of lawful explanations. Hempel's covering-law models emphasize structural or logical features of scientific explanation. Explanations of individual events (including such events as the presence of a particular feature on an artifact), according to these models, have the structure of arguments in which the explanandum follows (deductively or with high probability) from the explanans. Laws are necessary components of the explanans because they provide the appropriate logical link between the particular explanatory facts cited in the explanans and the explanandum. The laws in these models might be, but need not be, causal.

In Hempel's account, the statement that a feature has a particular function (a functional ascription) is one of the initial conditions in a functional explanation. Typically, what is to be explained is the presence of some feature in a system (for example, an organ in a human body or a custom in a society). The explanans includes a law to the effect that systems of that type require for their maintenance the satisfaction of specific requirements. Initial conditions mentioned in the explanans include a statement that the system is operating more or less satisfactorily and that the feature mentioned in the explanadum is capable of fulfilling the requirement mentioned in the law (1965). The anthropologist Radcliffe-Brown offers many functional explanations of customs in primitive societies. For example, he says that the pattern of somewhat abusive conduct of a man towards his mother-in-law (joking relationship) in some relatively isolated small societies has the function of preventing conflict that would undermine social stability. The joking relationship provides a harmless outlet for tension between potentially antagonistic pairs of relatives (1952, Ch. 4) Hempel regards this 
sort of explanation as incomplete since the explanadum cannot be derived from the explanans. Different features, "functionally equivalent" to that mentioned in the explanandum, could satisfy the specific requirement mentioned in the explanans. The "explanation" explains why there is some mechanism for avoiding conflict, but not why that particular custom serves the function. Anthropologists are well aware of functional equivalents. In another society studied by Radcliffe-Brown, for example, an avoidance relationship between son-in-law and his mother-in-law serves the same function as the joking relationship.

Nagel, whose views are close to Hempel's, has tried to solve the problem of functional equivalents by arguing that functional explanations can often be supplemented by historical and other considerations to rule out functional equivalents and to bring the explanations into accord with deductive-nomological or inductive statistical models (1977). Even when this can be accomplished, however, functional explanations cannot be causal explanations because the laws involved lack the proper temporal component. A law of the form "Societies of type A maintain stability only when a joking relationship exists between men and their mothers-in-law" permits the joking relationship to be contemporaneous with rather than antecedent to stability in the society.

Wright's account of functional ascription-explanation does not fit well with these models. In contrast to Hempel and Nagel, Wright discounts concern with structural features of explanation. Relying instead on the principle that a phenomenon is explained when its cause has been identified, Wright says that functional ascriptions are explanatory since they have etiological force-the item to which a function is ascribed exists, is where it is, because it has that function. Explanations, for Wright, need not be deductive or inductive arguments. Explanation consists in identifying the causes of phenomena. In Wright's analysis, the troubling question of functional equiv- 
alents loses force. Although different features could have been designed and employed to accomplish the same task, a functional ascription-explanation of a particular feature requires only that the required consequence etiology can be established for that feature.

Although the identification of causes is Wright's explanatory sine qua non, he provides no guidelines for recognizing causes and offers no analysis of the causal relationship itself. He maintains that causality is a primitive notion which cannot be elucidated in terms of any more fundamental relationship, and he says that at least in paradigm cases causal connections are immediately perceived. In ascribing functions to human artifacts, the inherent causal etiologies normally refer to human intentions. ${ }^{2}$ Like Donald Davidson (1980), Wright rejects the antimechanistic arguments of interpretivists who claim that because statements about the relationship between reasons for acting and the actions that arise from such reasons are analytic, there can be no causal mechanism connecting reasons with behavior (Wright, 1976, Ch. IV). Wright regards neurophysiological neductionism as a "plausible form of mechanism" which could provide "some law or rule governing the intention" (1976: 132). Explanations, for Wright, however, do not require the statement of such laws, for the causal relationship

2 Some qualification is necessary because specifying the intention that gives rise to an artifact's function is complicated. For example, from the perspective of the artisan's cultural tradition, the rabbit design on seedstorage bowls might be intended to insure a good harvest. But insuring a good harvest is not why the design "is there" in Wright's sense, for the design may not be efficacious. Following Merton's (and Radcliffe-Brown's) advice of seeking "latent" (or social) functions in such cases, we could say instead that the function of the design is to promote cultural or social solidarity. To justify this functional ascription, we try to establish that the design does promote solidarity, and to show that it "is there" as a result of helping to maintain a society in which painting rabbits on seed-storage bowls is culturally prescribed. Wright does not discuss latent functions, but his account can accommodate them. This note was prompted by a comment made by Raúl Orayen. 
between reason and action can be identified even in the absence of knowledge of the mechanism.

Nickles (1977) argues for the independence of singular causal explanation in the social sciences, with special reference to archaeology. He bases his case on our ability to detect singular causal relationships even when we are at a loss to identify appropriate causal laws to ground such judgments. Other authors, of course, disagree with this position, and have argued extensively that causal laws must underlie any singular attribution of causes (Hempel, 1966, W. Salmon, 1984). Davidson (1980), in his discussion of reasons and actions argues that we are sometimes justified in asserting that a particular reason is the cause of an action although we are unable to frame any appropriate underlying causal laws relating reasons to actions. Despite this, unlike Nickles, he insists that there must be some causal law to ground such claims. Davidson's position reveals the tension between the intuitive attraction of grounding singular causal claims in underlying causal laws and the special problems regarding the formulation of psychophysical laws. These issues are complex, but it at least is clear that the answer to our second question of whether functional ascription-explanations require laws depends on how the issue of singular causation vis-à-vis laws is resolved.

Pursuing our third question we ask, what would the laws that ascription-explanations depend on look like? This question is closely related to the previous one. Many authors are uncomfortable with insisting that causal laws are required to explain human behavior when these laws have proven so elusive. A look at Wright's (1976) explanation of why Cadillacs used to have fins will help focus on the relevant issues .

Wright says that the fins were there because of their popular appeal. Nevertheless, he notes that while the popular appeal of fins was the reason why (in the sense of causal etiology) Cadillacs had fins, popular appeal was neither a necessary nor a sufficient condition for the fins being there. The fins might . 
have been there for aerodynamic reasons, or they might not have been there despite popular appeal because they were too expensive to tool up for (1976: 83). He makes this point to demonstrate that the causal relationship cannot be understood in terms of necessary and sufficient conditions. Thus, "Whenever a feature has popular appeal, it will be included in the design of automobiles" cannot be the proper statement of the law that underlies Wright's singular causal claim. If there is an underlying law, what is it?

Several responses are possible. We could qualify the antecedent of the proposed law in various ways ("unless the feature is too expensive to tool up for" or "unless the design staff is unaware of the public's taste"). The number of such modifications, however, seems to be limited only by the fertility of our imaginations. We could add an "all things being equal" or ceteris paribus clause, but normally all things are not equal.

We could point out that causal laws need not be deterministic and try to frame a probablistic version of the law. We probably lack statistical evidence that would enable us to frame a law of the form "In $z$ per cent of cases...". A vague probabilistic law, such as "Usually, when a feature has popular appeal, it is incorporated into the design of a mass-produced item", however, is not noticeably distinct in meaning from the universal form with ceteris paribus clause. Even if we had statistical data, we would not be comfortable with using them to frame a law unless we were persuaded that the statistics captured something "real". But how or by what evidence would we be persuaded? Merely changing the form to that of a probabilistic rather than deterministic law does not avoid the problem of how to make the law precise, general, and "strong" enough to be worthy of the name.

Critics of laws in the social sciences (e.g., MacIntyre, 1982) point to these problems, and contrast the vague ceteris paribus clauses of so-called laws in the social sciences with the high degree of specification of boundary conditions on physical laws. 
For example, although the ideal gas laws are subject to the qualifying clause "under moderate temperature and pressure", this constraint can be spelled out precisely, whereas in the social sciences ceteris paribus clauses are vague and open ended.

A closer look at physical laws, however, shows that they are not strikingly different from laws in the social sciences. Physical laws similarly fail to specify all of the conditions under which the law would not apply. Whereas it is true that statements of physical laws do not explicitly invoke ceteris paribus clauses, Hempel points out in his recent paper "Provisoes" (1988), that such clauses are nevertheless implicit. He argues, for example, that physical laws neither state precisely how all of the various surrounding circumstances could interfere with their operation nor that such conditions will not occur.

In the history of the physical sciences, an important focus of empirical investigations has been to specify increasingly precise boundary conditions for many physical laws. Ceteris paribus clauses in the statement of laws of social science can and sometimes do suggest where research efforts should be directed to attain more precise qualifying conditions. Market analysis, psychological or anthropological research might enable us to frame boundary conditions for a causal law relating popular appeal and features of expensive mass-produced objects, such as automobiles, that serve both utilitarian and expressive functions.

This optimistic approach must be tempered, however, by the acknowledged failure of social scientists to come up with many (some would say any) interesting laws, as opposed to mere summaries of practices within a given culture or historical period. Although the latter summaries might have predictive value, and can even afford some insights into individual and social behavior, they somehow lack the force of explanatory laws. We feel keenly their limitations to time, place, and other circumstances, and when we try to generalize by stripping those limits away we are left with truisms. Some archaeologists 
have tried to avoid problems with behavioral laws by relying only on well-supported physical laws (Dunnell 1985, 1989). As noted earlier, some of the attributions of function made by archaeologists are strongly grounded in physical properties of the features that show traces or marks of interaction with some aspect of the physical environment. Striations made by brush strokes can be detected on pottery surfaces long after traces of paint have faded. Physical laws of abrasion and minute traces of substances provide strong support for claims that tools and containers were used in specific ways. In view of these considerations, we can ask whether at least some functional ascriptionexplanations are completely grounded in physical laws. The answer to this question is negative if we adopt Wright's analysis of functional ascription. Physical laws can support the claim that a piece of stone shaped by a human functioned as a hide scraper; but $a$ further inference, not grounded in physical laws, is required to support the claim that hide scraping was its function (that the reason that the stone "is there" or has the form it has is its usefulness for scraping hides). Insofar as archaeologists are interested in ascriptions of functions, they must take into account purposive behavior or actions I make this point not to cast doubt on functional ascriptions, but only to indicate that one cannot completely bypass intentional considerations in offering ascription-explanations of human artifacts.

Philosophical criticism of attempts to formulate laws that connect intentions with behavior has been sustained on several fronts. Although Davidson believes that reasons are causes of actions, he says that numerous counterexamples show us that the causal laws that underlie human behavior cannot be formed by generalizing such causal claims. Davidson believes that eventually laws that ground singular causal statements about human intentional behavior may be found, but that they will not be psychophysical laws of any sort. Apparently, in his view, the discovery of the appropriate underlying laws waits on the successful development of our understanding of neurophys- 
iology. Alexander Rosenberg (1988) also points to the failure of social science to go beyond folk psychology in framing laws of the form "Given any person $x$, if $x$ wants $d$ and $x$ believes that $a$ is a means to attain $d$, under the circumstances, then $x$ does $a$ ". He argues that this formulation "turns out not even to be of limited employment as a causal regularity, for the elements it connects cannot even in principle be shown to bear contingent relations to one another" (1988: 49). These difficulties about laws pose serious problems for archaeological theory insofar as it is concerned with explaining material remains in terms of human intentional behavior.

That archaeology is no worse off than any other social science in this respect may not be particularly comforting to those committed to a view of archaeology as a social science, but foundational problems with laws of human behavior need not paralyze attempts to construct explanations in archaeology. After all, foundational problems concerning the nature of physical and biological laws have not halted explanatory efforts in physics or biology.

In that spirit, let us assume that despite the foundational problem discussed above, the project of explaining archaeological materials in behavioral terms is not totally misguided. ${ }^{3}$ This assumption is shared by new archaeologists and their postprocessual critics. New archaeologists, however, have been extremely wary of trying to ascribe functions to archaeological materials in the absence of any close historical or ethnographic analogues and detailed physical evidence. As mentioned earlier, they have been more reluctant than postprocessualists to ascribe symbolic or expressive functions, that is to say, "to assign meanings", to features that do not bear traces of specific interactions with the physical environment. Many of the debates that exercise contemporary archaeologists focus on this

3 Dunnell, who considers the social science model entirely inappropriate would reject this assumption. 
point. The disagreement is sometimes characterized as a struggle between the scientific new archaeologists who seek (lawful) explanations and the humanistic postprocessualists who instead seek understanding, or meanings while either ignoring or denying laws. More accurately, the two groups disagree about the following points:

(l) the importance of symbolic or expressive aspects of human behavior for acquiring adequate understanding (or explanations) of people known through their archaeological remains;

(2) the availability and quality of evidence to support the generalizations (laws) required to understand or explain archaeological findings in terms of symbolic behavior. Both groups recognize the central role of functional ascription, and, insofar as our analysis of ascription-explanation is applicable, both are concerned with intentional behavior of humans and with explanatory laws.

Having noted the common concerns, I now want to focus on the differences. New archaeologists have dismissed some attempts to reconstruct symbolic behavior of people known only through their archaeological remains as futile "paleopsychology" because, they say, neither analogical nor physical evidence is strong enough to support the required inferences. Ian Hodder, in contrast, claims that rigorous procedures can be developed for ascribing detailed expressive or symbolic functions, which he also calls "subjective meanings" and "symbolic meanings" (1987b: vii). Hodder develops his account of "contextual archaeology" to overcome criticisms that ascriptions of symbolic functions in his earlier (1982) were scientifically unacceptable. An examination of this work, however, will show that insofar as the procedures suggested by Hodder have any rigor, they are identical with procedures already accepted and used by new archaeologists. Hodder's contribution in his (1987b) work is a new set of lawlike principles rather than new procedures. 
Hodder correctly notes that new archaeologists themselves assign meanings to archaeological remains. As we have seen, intentional (i.e., meaningful) behavior is attributed to the producers or users of human artifacts even when utilitarian functions are ascribed to them. We can go further than Hodder and point out that new archaeologists also frequently assign symbolic functions to archaeologically known features. For example, new archaeologists routinely explain the presence of valuable grave goods as expressions of the high status of the deceased. Although symbolic functions rarely impart physical traces that permit the identification of those functions, relevant historical and ethnographic analogies can often support the claim that an item was used for or good for a particular purpose, and that the item "is there" because it served that purpose. The point of disagreement between new archaeologists and postprocessual archaeologists is not, therefore, whether or not meanings (intentions) are involved in the functional ascriptions, or even whether symbolic behavior can ever be inferred, but rather the nature of the evidence to support such ascriptions.

Questions about the quality of evidence can be asked separately about each of Wright's two conditions for ascribing functions:

(1) Identifying what an item was good for or used for;

(2) Determining whether it "is there" for that reason (has the proper causal etiology).

For features with utilitarian functions, either traces of physical interactions or ethnographic or historical analogies can be used to infer what an item was good for or used for. Analogies provide a major source of evidence for symbolic uses of items, as well as evidence for the requisite causal etiologies for both symbolic and utilitarian functions. Since the range of forms for features with symbolic functions is less restricted than for features with primarily utilitarian functions, historical and ethnographic analogies, even when available, are less compelling in 
symbolic cases. Obviously, arguments for ascribing functions depend on the context of the feature as well as its form. Ascription arguments are inductive and vary in strength according to available evidence.

Postprocessual archaeologists, following the lead of Ian Hodder, insist that despite difficulties archaeologists can and must discern symbolic or expressive functions of the materials they study if they are to understand adequately the behavior of archaeologically known peoples.

Hodder believes symbolic meanings can be approached by first performing statistical analyses of similarities and differences along traditional archaeological dimensions such as space and time, and then assuming some "universal 'language' in which similarities and differences are meaningful" (1987b: 5). The existence of this universal language, according to Hodder, allows us to frame some general principles (laws) such as "Similarities and differences are constructed by making boundaries between things... and repeating and correlating the same categories along different dimensions" (p. 7). These principles, along with detailed knowledge of archaeological contexts, are invoked to support ascription-explanations of archaeological materials. Hodder admits that multiple interpretations of symbolic functions are always possible. In fact, Hodder acknowledges, but offers no answer to, most of the standard criticisms of attempts to assign meanings to phenomena in cultures spatially or temporally distant from our own. Despite this, however, he maintains that "other historical contexts with their unique frameworks of meaning car be understood through an examination of material culture" (p. 10), and he proposes to demonstrate his claim through the case studies that comprise the book. Before turning to a specific example, it should be noted that Hodder's principles and his claim that a universal language can be read to discern the meanings of similarities and differences constitute a novel approach to archaeological 
explanation which would not be accepted by most new archaeologists.

To exemplify his new "rigorous procedures" for assigning meanings, Hodder discusses an unpublished study of prehistoric iron-smelting furnaces in one region of East Africa (Collett, 1985). The study begins with measurements along several spatial dimensions of excavated furnaces. On the basis of various measures, the investigator divided the furnaces into two categories: deep and shallow. "Significant correlations" were also found to support an association between deep furnaces, decorated furnace bricks, and high iron slag. A corresponding association connected shallow furnaces, undecorated bricks and low iron slag. Metallurgical analysis of the two forms of slag and "analogies with other pre-industrial smelting processes" (1987b: 5) indicate that the deep furnaces were used to smelt ore whereas the shallow furnaces were used for resmelting to refine the iron. Assuming that Collett's statistical correlations are in order, most archaeologists would regard these functional ascriptions to the two types of furnace as unproblematic even though there is no explicit concern with establishing the claim that the different types of furnaces "are there" because they are "good for" the two different types of smelting. That is to say, the procedures used thus far would be recognized as "rigorous" by new archaeologists, but these procedures constitute no novelty in Hodder's position, as he would himself admit.

Cooking pots with decorations similar to those on the decorated furnace bricks are also found near those bricks and the deep furnaces. Hodder claims that it is possible to explain also the similarity between the decorations on the bricks and the cooking pots. He believes that the "context" which associates cooking pots with one type of furnace can provide the explanatory link that will allow the archaeologists to "read" the universal language of relevant similarities and differences. At this point we expect his new methods to be revealed. 
Hodder's approach requires the archaeologist "to imagine a dimension of variation that ma[kes] sense of the link between deep furnaces and cooking pots" (p. 6). Since scientific reasoning has traditionally benefitted from imagination, his suggestion is hardly novel. Little imagination is required in any case to connect cooking and smelting on the grounds that both involve using heat to transform material. Hodder also cites ethnographic and historic studies conducted by Collett (1985) to support his claim that the decoration on the furnaces has a symbolic function. Collett has shown that furnaces in a number of African cultures have forms or decoration which serve expressive functions (for example, fertility motifs) that are explicitly acknowledged by the people who manufacture and use the furnaces. New archaeologists would readily agree that Collett's analogies are good evidence that the decorated bricks associated with the archaeologically known furnaces served some expressive function.

Hodder, however, goes beyond this general conclusion to state that the similar decorations on bricks associated with the deep furnace and the decorations on the cooking pots can be interpreted in terms of the "general anthropological understanding of nature/culture, raw/cooked dichotomies" (p. 6). In addition, Hodder explains the lack of decoration on the shallow furnaces, which would appear to involve transformation by heat as well, by saying that a second smelting involves only refinement and not transformation.

Hodder's symbolic ascription-explanation of the similar decorations on cooking pots and furnace bricks dependsultimately on his principles or "laws" for reading similarities and differences, since the other evidence that Hodder cites cannot support his specific interpretation. Although his principle would be judged too vague to support such an interpretation by new archaeologists, who would deny that Hodder has succeeded in providing a "rigorous procedure" for ascribing symbolic functions, Hodder's work does bring out the central role that laws 
play in archaeological explanations offered by postprocessualists.

It is fair to say that Hodder's novel contribution to archaeological interpretation or explanation in this work resides in his proposal of new explanatory laws. In Hodder's introductory example, as in many other case studies presented in The Archaeology of Contextual Meanings, these novel explanatory laws play a crucial though often unacknowledged role. Thus Dunnell's claim that "The immediate impact of the revelation that no single model of science was unchallenged in philosophy was a cessation of archaeological interest in the kinds of philosophical discussion that had characterised archaeological journals in the early and middle 1970's" (1989: 7), should not be interpreted as an indication that archaeologists are no longer interested in the possibility of lawful explanation in archaeology. In fact, we can describe the gulf that separates the new archaeologists from their postprocessual critics as a strong disagreement about the sorts of laws that can be used to explain archaeological phenomena.

\section{BIBLIOGRAPHY}

Binford, L.R., 1972, An Archaeological Perspective, New York: Harcourt.

Collett, D., 1985, “The Spread of Early Iron-Producing Communities in Eastern and Southern Africa", unpublished Ph. D. dissertation, University of Cambridge.

Davidson, D., 1980, Essays on Actions and Events, Oxford: Clarendon Press.

Dunnell, R., 1978, "Style and Function: A Fundamental Dichotomy", American Antiquity 43, pp. 192-202.

$\longrightarrow, 1985$, "Methodological Issues in Contemporary Americanist Archaeology", in P. Asquith and P. Kitcher (eds.), PSA 1984, vol. 2, Proceedings of the 1984 Biennial Meeting of the Philosophy of Science Association, East Lansing, MI, pp. 719-44. 
, 1989, "Philosophy of Science and Archaeology", in Critical Traditions in Contemporaly Archaeology, V. Pinsky and A. Wylie (eds.), Cambridge: Cambridge University Press, pp. 5-9.

Flannery, K., and M. C. Winter, 1976, "Analyzing Household Activities", in The Early Mesoamerican Village, K. Flannery (ed.), New York: Academic Press, pp. 34-47.

Gombrich, E., 1968, "Style", in International Encyclopedia of the Social Sciences, 15, pp. 352-361.

Hempel, C. G., 1965, Aspects of Scientific Explanation, New York: The Free Press.

- 1966, Philosophy of Natural Science, Englewood Cliffs, N.J.: Prentice-Hall.

- 1988, "Provisoes: A Problem Concerning the Inferential Functions of Scientific Theories", Erkenntnis 28, pp. 147-64.

Hempel, C. G. and P. Oppenheim, 1948, "Studies in the Logic of Explanation", Philosophy of Science 15, pp. 135-75.

Hodder, I., 1985, "Digging for Symbols in Science and History: A Reply", Proceedings of the Prehistoric Society 51, pp. 352-356.

- (ed.), 1982, Symbolic and Structural Archaeology, Cambridge: Cambridge Univesity Press.

_-, 1987a, Archaeology as Long-Term History, Cambridge: Cambridge University Press.

_ 1987b, The Archaeology of Contextual Meanings, Cambridge: Cambridge University Press.

MacIntyre, A., 1984, After Virtue, Notre Dame: University of Notre Dame Press.

Meehan, E., 1968, Explanation in Social Science-A Systems Paradigm, Homewood, IL: The Dorsey Press.

Morgan, C., 1973, “Archaeology and Explanation”, World Archaeology 4, pp. 259-276.

Nagel, E., 1977, "Teleology Revisited: The Dewey Lectures", The Journal of Philosophy 74, pp. 261-301.

Nickles, T., 1977, "On the Independence of Singular Causal Explanation in the Social Sciences: Archaeology", Philosophy of the Social Sciences 7, pp. 163-187.

Radcliffe-Brown, A., 1952, Structure and Function in Primitive Society, Glencoe: The Free Press.

Rosenberg, A., 1988, Philosophy of Social Science, Boulder: Westview Press. 
Sackett, J., 1982, “Approaches to Style in Lithic Archaeology", Journal of Anthropological Archaeology 1, pp. 59-112.

Salmon, M., n.d., "Post-processual Explanation in Archaeology: Whose Child is This?" Paper presented at the First Joint Archaeological Congress, Baltimore, January 7, 1989.

Salmon, M. and W. Salmon, 1979, "Alternative Models of Scientific Explanation", American Anthropologist 81, pp. 61-74.

Salmon, W., 1984, Scientific Explanation and the Causal Structure of the World, Princeton: Princeton University Press.

Schiffer, M., 1976, Behavioral Archaeology, New York: Academic Press.

Shanks, M. and C. Tilley, 1987, Social Theory and Archaeology, Albuquerque: University of New Mexico Press.

Trigger, B., 1978, Time and Traditions, New York: Columbia University Press.

Tuggle, D., A. H. Townsend, and T. Riley, 1972, "Laws, Systems, and Research Designs", American Antiquity 37, pp. 3-12.

van Fraassen, B., 1989, Laws and Symmetry, Oxford: Oxford University Press.

Watson, P. J., S. LeBlanc, and C. Redman, 1971, Explanation in Archaeology: An Explicitly Scientific Approach, New York: Columbia University Press.

—, 1984, Archaeological Explanation, New York: Columbia Univesity Press.

Wright, Larry, 1976, Teleological Explanations, Berkeley and Los Angeles: University of California Press.

Wylie, A., 1990, “A Proliferation of New Archaeologies: Scepticism, Processualism, and Post-Processualism", paper presented to the Department of Archaeology, Boston University.

Recibido: 2 octubre 1990. 


\section{RESUMEN}

El trabajo consiste en examinar la posibilidad de que, en la arqueología, se den explicaciones que recurran a leyes. Muchos arqueólogos trataron de convencer a sus colegas de que adoptaran el modelo nomológico deductivo de explicación y el modelo hipo:ético deductivo de confirmación, siguiendo la propuesta de Hempel. Otros arquéologos, como Tuggle, han recurrido a un modelo alternativo de explicación basado en el llamado "acercamiento de sistemas"; este último modelo supone regularidades en lugar de leyes.

Los arqueólogos han tratado de responder a la pregunta de por qué un objeto o una característica de un objeto se encuentran en un contexto arqueológico dado. Las respuestas a menudo se dan recurriendo a "la función" del objeto o de la característica del objeto. De este manera, la adscripción de una función proveé el nexo fundamentalmente entre los objetos que persisten y la conducta de las personas que nos son conocidas a través de esos objetos.

Los problemas acerca de la justificación de la adscripción de funciones están relacionados con la cuestión sobre la posibilidad de explicar recurriendo a leyes. Para algunos autores, que no siguen el modelo hempeliano, explicar recurriendo a leyes es explicar “causalmente". Uno de los autores que defiende esta posición es Larry Wright, quien afirma que cuando adscribimos una función a un artefacto hecho por humanos estamos diciendo que el objeto fue seleccionado, diseñado, creado, o modificado para llevar a cabo una consecuencia deseada. Esta afirmación nos dice algo acerca de por qué el objeto es o llegó a ser, o tiene la forma que tiene. De esta manera, las adscripciones funcionales nos dicen algo sobre la historia causal del objeto, es decir, las explicaciones funcionales recurren a una etiología causal.

La fuerza explicativa de las adscripciones funcionales depende de la distinción entre la función de un objeto o de una característica del objeto y un uso propositivo, pero que es accidental o incidental.

Una pregunta que surge después de haber analizado lo que significa adscribir una función es: ¿las explicaciones de adscripción de función dependen de leyes? Una manera de contestar la pregunta es tratar de ajustar las explicaciones de adscripción de función al modelo hempeliano. El problema con este modelo es que siempre pueden surgir equivalentes funcionales. 
Otra respuesta la da Wright, para quien el problema de las leyes está conectado con la causalidad y no con la característica estructural de la explicación. Ahora bien, para Wright una relación causal no tiene por qué ser entendida en términos de condiciones necesarias y suficientes. Esta posición nos permite afirmar que las leyes causales no tienen que ser deterministas, sino que admiten cláusulas ceteris paribus.

Muchos críticos del uso de leyes en ciencias sociales han afirmado que las cláusulas ceteris paribus, en esas disciplinas, son demasiado vagas $y$ ambiguas.

Otros arqueólogos han recurrido, en la arqueología, a las leyes físicas y biológicas para evitar los problemas relacionados con las leyes de la conducta, sin embargo este intento ha fracasado porque al arqueólogo le interesan las acciones humanas propositivas. Por está razón el proyecto de explicar los materiales arqueológicos en términos de la conducta de los hombres no es errado. Prácticamente el debate actual se ha dado dentro de esta posición.

El debate lo han llevado a cabo dos grupos de arqueólogos: los nuevos arqueólogos científicos, que buscan explicaciones recurriendo a leyes y los arqueólogos posprocesalistas humanistas, que buscan "entender", ignorando el asunto de las leyes. El desacuerdo entre estos dos grupos es acerca de la evidencia que se necesita para fundamentar una adscripción de función.

Los dos grupos no están de acuerdo en los puntos siguientes:

(1) la importancia de los aspectos simbólicos o expresivos de la conducta humana para adquirir una comprensión o explicación de las personas que nos son conocidas por sus objetos persistentes;

(2) la viabilidad y la calidad de la evidencia que tenemos para fundamentar las generalizaciones (o leyes) que necesitamos para comprender o explicar los hallazgos arqueológicos en términos de una conducta simbólica.

Ahora bien, esta disputa no puede ser interpretada como una falta de interés de los arqueólogos en los modelos de explicación de la ciencia. Más bien, podemos interpretar el abismo que separa a estos grupos como un profundo desacuerdo entre dos clases de leyes que pueden explicar el fenómeno arqueológico.

[Pauletue Dieverlen] 